\title{
Implementasi Kebijakan Pembinaan UMKM di Kabupaten Subang
}

\section{Iwan Henri Kusnadi ${ }^{1}$}

Fakultas Ilmu Administrasi Universitas Subang Iwanhenri01@gmail.com

\section{Luki Natika ${ }^{2}$}

Fakultas Ilmu Administrasi Universitas Subang lukinatika85@gmail.com

\section{Dyera Octa Alsonia ${ }^{3}$}

Fakultas Ilmu Administrasi Universitas Subang alsoniadyeraocta@gmail.com

\begin{abstract}
Abstrak
Tujuan penulis melakukan penelitian ini adalah untuk mengetahui Implementasi Kebijakan Dalam Pembinaan UMKM Pada Dinas Koperasi, UMKM, Perdagangan, dan Perindustrian Kabupaten Subang. Penelitian dan penulisan ini membahas hal-hal yang berkaitan dengan Impelementasi Kebijakan dalam Pembinaan UMKM Pada Dinas Koperasi, UMKM, Perdagangan, dan Perindustrian dengan teori Merilee S. Grindle yaitu Isi kebijakan terdiri dari Kepentingan kelompok sasaran, Tipe Manfaat, Derajat Perubahan yang diinginkan, Letak pengambilan keputusan, pelaksanaan program, sumberdaya yang dilibatkan. Lingkungan Impelementasi terdiri dari Kekuasaan, kepentinganm dan strategi aktor yang terlibat, karakteristik Lembaga dan penguasaan. Dalam penelitian ini menggunakan pendekatan kualitatif melalui pengamatan dan observasi, wawancara, studi keperpustakaan dan dokumentasi, sumber data diperoleh dari informan melalui pengamatan dan wawancara secara langsung dan dokumen diperoleh dalam bentuk hasil wawancara dan pengolahan data. Hasil penelitian menunjukan bahwa Impelementasi kebijakan Dalam Pembinaan UMKM Pada Dinas Koperasi, UMKM, Perdagangan, dan Perindustrian Kabupaten subang sudah efektif pada Tipe manfaat, Derajat perubahan yang diinginkan, Letak pengambilan keputusan, Pelaksanaan program, Sumberdaya yang dilibatkan, Karakteristik Lembaga dan penguasan, kepatuhan dan daya tangkap, sedangkan pada kepentingan kelompok sasaran, kekuasaan, kepentingan, dan strategi aktor yang terlibat, belum efektif.
\end{abstract}

Kata kunci : Implementasi Kebijakan

\section{Abstract}

The purpose of the authors of this research is to determine the implementation of policies in the development of UMKM at the Cooperatives, UMKM, Trade, and Industry Office of Subang 


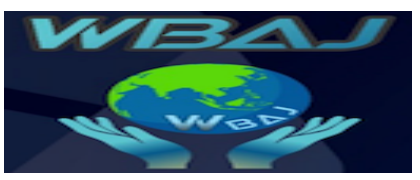

Volume 2 Issue 2, Desember 2020

https://ejournal.unsub.ac.id/index.php/bisnis

Regency. This research and writing discusses matters related to the implementation of policies in the development of UMKM at the Cooperatives, UMKM, Trade and Industry offices with the Merilee S. decision making, program implementation, the resources involved. The implementation environment consists of the power, interests and strategies of the actors involved, the characteristics of the institution and the power. In this study, using a qualitative approach through observation and observation, interviews, library research and documentation, data sources were obtained from informants through direct observation and interviews and documents were obtained in the form of interviews and data processing. The results showed that the implementation of policies in the development of UMKM at the Office of Cooperatives, UMKM, Trade, and Industry of Subang Regency was effective on the type of benefit, the degree of change desired, the location of decision making, program implementation, the resources involved, the characteristics of the institution and the mastery, compliance and capturing power, while in the interests of the target group, the power, interests and strategies of the actors involved, it is not yet effective.

\section{Keywords: Policy Implementation}

\section{Pendahuluan}

Implementasi kebijakan adalah bagian dari rangkaian proses kebijakan publik. Proses kebijakan adalah suatu rangkaian tahap yang saling bergantung yang diatur menurut urutan waktu, penyusunan agenda, formulasi kebijakan adopsi kebijakan dan penilaian kebijakan. Kebijakan yang telah direkomondasikan untuk di pilih oleh policy makers bukanlah jaminan bahwa kebijakan tersebut pasti berhasil dalam mengimplementasikan.

Implementasi kebijakan merupakan faktor penting dalam sebuah kebijakan. Di mana implementasinya sebuah kebijakan akan mengandung resiko kegagalan bila tidak terimplementasikan dengan baik. Tidak terimplementasikan disini mengandung arti bahwa suatu kebijaksanaan tidak terlaksanakan sesuai dengan rencana, tidak efisien dalam pekerjaanya atau kurangnya kerjasama antar pihak- pihak pelaksana, yang tentunya akan berakibat terhadap implementasi yang efektif sukar untuk dicapai.

Kebijakan Usaha Mikro, Kecil, dan Menengah (UMKM) merupakan salah satu bidang usaha yang dapat berkembang dan konsisten dalam perekonomian nasional. UMKM menjadi wadah yang baik bagi penciptaan lapangan pekerjaan yang produktif. UMKM merupakan usaha yang bersifat padat karya, tidak membutuhkan persyaratan tertentu seperti tingkat pendidikan, keahlian (keterampilan) pekerja, dan penggunaan modal usaha relatif sedikit serta teknologi yang digunakan cenderung sederhana. Usaha mikro adalah usaha produktif milik perorangan atau badan usaha perorangan yang memenuhi kriteria, usaha kecil adalah usaha ekonomi produktif yang berdiri sendiri yang dilakukan oleh perorangan atau badan usaha yang merupakan anak perusahaan atau bukan cabang yang dimiliki, di kuasai, atau menjadi bagian baik langsung maupun tidak langsung dari usaha menengah atau besar yang memenuhi kriteria usaha kecil. Usaha menengah adalah usaha ekonomi produktif yang berdiri sendiri yang dilakukan oleh perorangan atau badan usaha yang bukan merupakan anak perusahaan atau cabang perusahaan yang di miliki, di kuasai, atau menjadi bagian baik langsung maupun tidak langsung dengan usaha kecil atau usaha besar dengan 
jumlah kekayaan bersih atau hasil penjualan tahunan.

Kebijakan UMKM di atur dalam regulasi tersendiri yaitu UU Nomor 20 tahun 2008 yang menjelaskan mengenai peraturan - peraturan UMKM. Kriteria UMKM dijelaskan dalam UU tersebut bahwa dunia usaha di bedakan menjadi Usaha mikro, kecil, dan menengah. Segmentasi usaha mikro, kecil, dan menengah di golongkan secara khusus karena mewakili segmen rakyat kecil dengan sebutan usaha mikro, kecil, dan menengah (UMKM). Berdasarkan UU tersebut UMKM adalah Usaha Produktif yang memenuhi kriteria usaha dengan Batasan tertentu kekayaan bersih dan hasil penjualan tahunan. Keberadaan UMKM ini tidak boleh dipandang sebelah mata. Umkm merupakan salah satu sektor strategis dalam perekonomian nasional. Tujuan UMKM yaitu menumbuhkan dan mengembangkan usahanya dalam rangka membangun perekonomian nasional berdasarkan demokrasi ekonomi yang berkeadilan. Perkembangan UMKM dari tahun ke tahun mulai berkembang pesat besarnya minat masyarakat untuk berwirausaha atau mengembangkan usahanya kembali sebagai mata pencaharian sangatlah besar.

Dinas Koperasi, UMKM, Perdagangan dan perindustrian Kabupaten Subang salah satu tugasnya untuk mengembangkan UMKM Akan tetapi yang menjadi permasalahan saat ini pelaku UMKM belum memiliki kerjasama manajerial yang memadai pembinaan oleh pemerintah dalam bentuk pelatihan terhadap UMKM, tetapi masih terbatas belum mencapai sasaran. kebijakan pemerintah daerah meningkatkan bisnis UMKM dalam bentuk permodalan masih kurang atau terbatas sehingga UMKM banyak yang terlibat lintah darat diantaranya bank emok, perananan sektor swasta dalam mendukung kebijakan pembinaan UMKM belum optimal. yang membelit pelaku masyarakat adalah sebagai berikut. terutama para pelaku usaha mikro dan kecil. Fenomena kurangnya modal para pelaku usaha mikro dan kecil, dimanfaatkan oleh para pemilik modal perorangan atau bank emok, Mereka berusaha meminjamkan modalnya kepada masyarakat. pemerintah daerah harus lebih meningkatkan kebijakan pembinaan terhadap UMKM, karena akan diteliti. Diharapkan dengan adanya koperasi yang ada di setiap desa dapat mengkordinir kebutuhan permodalan masyarakat. Kesenjangan atas harapan masyarakat dan kenyataan yang ada sebagaimana telah dikemukakan di atas akan berdampak lebih buruk jika pemerintah tidak antisipatif dalam memecahkan persoalan-persoalan tersebut dan persoalan pemerintah lainnya. Dampak yang secara pasti akan timbul adalah posisi lapisan bawah akan semakin tidak berdaya, oleh karena masyarakat yang kondisi ekonominya lebih baik akan lebih mampu melakukan akses terhadap peluang-peluang yang terbuka pada saat ini. Adapun bantuan permodalan untuk UMKM terdiri dari Bank BRI, BJB, BNI Berupa KUR dengan berbunga ringan akan tetapi tidak semua UMKM diberikan pinjaman permodalan.

Kebijakan yang dibuat oleh pemerintah daerah berupa Program pembinaan untuk UMKM salah satunya dengan adanya pelatihan bagi pelaku UMKM di Kabupaten Subang. sesuai dengan Visi JAWARA bupati dan wakil bupati subang yang berkeinginan untuk membangkitkan kembali kejayaan UMKM oleh Dinas Koperasi, Perdagangan dan Perindustrian Kabupaten Subang. Akan tetapi Kebijakan Program Pembinaan UMKM dikabupaten Subang perlu di tingkatkan lagi agar lebih berkembang dan maju Serta Unggul. 
Tabel 1.1

Data Program Pembinaan UMKM di Dinas Koperasi, UMKM, Perdagangan Dan Peindustrian Kabupaten Subang

\begin{tabular}{|c|c|c|}
\hline Jenis & Tahun 2019 & Keterangan \\
\hline UMKM & 24.158 & Belum terbina (pertahun dibina 240 usaha) \\
\hline Kecil & 25.625 & Belum terbina (pertahun dibina 240 usaha) \\
\hline Menengah & 29.450 & Belum terbina (pertahun dibina 240 usaha) \\
\hline
\end{tabular}

\section{Sumber : Dinas Koperasi UMKM, perdagangan, dan Penindustrian.}

Berdasarkan data diatas, Keberhasilan UMKM tentu adanya dukungan kebijakan dari pemerintah daerah Karena perannya tersebut, maka UMKM perlu terus menerus dilatih dan dan mendapat pembinaan secara berkelanjutan agar dapat lebih berkembang dan maju. Pembinaan merupakan proses atau pengembangan yang mencakup urutan-urutan pengertian, diawali dengan mendirikan, menumbuhkan, memelihara pertumbuhan tersebut yang disertai usaha-usaha perbaikan, menyempurnakan dan mengembangkannya. Sasaran dari pembinaan usaha kecil menengah adalah untuk mengembangkan usahanya menjadi lebih besar. Dalam Peraturan Pemerintah Republik Indonesia nomor 17 tahun 2013, tentang pengembangan usaha UMKM, Kemitraan, perizinan, koordinasi dan pengendalian pemberdayaan UMKM dan ketentuan peralihan dalam pasal 2 PP ini, pemerintah dan pemerintah daerah sesuai dengan kewenangannya Penyelenggaraan Pemberdayaan UMKM dengan; pengembangan usaha, kemitraan, perizinan dan koordinasi dan pengendalian. Terkait dengan pengembangan usaha terhadap UMKM, sesuai pasal 5 PP ini, dilakukan melalui; pendataan identifikasi potensi, dan masalah yang dihadapi, penyusunan program pembinaan dan pengembangan, dan pemantauan pengendalian pelaksanan program. pembinaan adalah suatu proses atau pengembangan yang mencakup urut-urutan pengertian, diawali dengan mendirikan, menumbuhkan, memelihara pertumbuhan tersebut yang disertai usahausaha perbaikan, menyempurnakan dan mengembangkannya.

Dari definisi di atas dapat disimpulkan bahwa pembinaan adalah upaya yang dilakukan pemerintah, dunia usaha dan masyarakat melalui pemberian bimbingan dan penyuluhan untuk menumbuhkan dan meningkatkan kemampuan usaha kecil agar menjadi usaha yang tangguh dan mandiri serta dapat berkembang menjadi usaha menengah. Dalam Peraturan pemerintah RI Nomor 17 tahun 2013 Tentang usaha mikro, kecil, dan menengah. Pembinaan dan pengembangan usaha kecil dilakukan oleh pemerintah, dunia usaha dan masyarakat, baik secara sendiri-sendiri maupun bersama-sama dan dilakukan secara terarah,terpadu dan berkesinambungan. Poin penting yang diatur dalam PP ini adalah pemerintah pusat dan pemerintah daerah untuk memfasilitasi pengembangan UMKM. Pembinaan dan pengembangan usaha kecil dilakukan dengan cara-cara sebagai berikut: (1) Identifikasi potensi dan masalah yang dihadapi oleh usaha kecil, (2) Penyiapan program pembinaan dan 


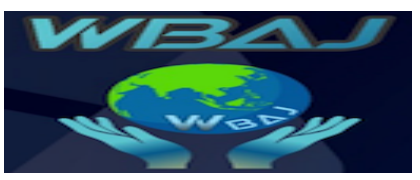

Volume 2 Issue 2, Desember 2020

https://ejournal.unsub.ac.id/index.php/bisnis

pengembangan sesuai potensi dan masalah yang dihadapi oleh usaha kecil, (3) Pelaksanaan program pembinaan dan pengembangan, dan (4) Pemantauan dan pengendalian pelaksaan program pembinaan dan pengembangan bagi usaha kecil. Pembinaan dan pengembangan usaha kecil yang dilaksanakan oleh dunia usaha dan masyarakat berupa: (1) Penyediaan tenaga konsultan profesional, sarana, prasarana, teknologi, dana dan informasi, (2) Bimbingan dan konsultan, (3) Pendidikan dan pelatihan, (4) Advokasi, dan (5) Pendirian klinik konsultasi bisnis untuk usaha kecil. Menurut Dewi, 2008 dalam Alhampi, Raden (2013), kegiatan pembinaan tidak terlepas dari adanya faktor pendukung dan faktor penghambat. Faktor pendukung meliputi: (1) Ketersediaan dana, (2) Jalinan kerjasama dengan instansi lain, dan (3) Ketersediaan sarana dan prasarana. Sedangkan faktor penghambat pembinaan antara lain: (1) Keterbatasan sumber daya manusia, (2) Ketidakmampuan pengusaha mengembalikan pinjaman, (3) Keterbatasan jumlah pegawai, dan (4) Keterbatasan informasi.

Pengembangan Pemasaran Produk UKM di Kabupaten Subang menjadi langkah yang sangat penting dalam konteks perencanaan pembangunan sektor ekonomi umumnya dan sektor Usaha Kecil dan Menengah (UKM) sebagaimana menjadi Gelora JAWARA. Pengembangan UKM Kabupaten Subang tidak dapat dilepaskan pula dari penentuan berbagai sektor dan stakeholders untuk membangun potensi ekonomi yang layak dikembangkan, maka penyusunan perencanaan pembangunan Kabupaten Subang diharapkan lebih terarah sehingga merangsang terciptanya pembangunan yang berkelanjutan berdasarkan semangat Jaya Istimewa dan Sejahtera yang sedang dijadikan nilai dan semangat pembangunan di

Kabupaten Subang saat ini. Saat ini implementasi kebijakan dalam membangun Usaha Mikro, Kecil dan Menengah (UMKM) di Kabupaten Subang masih perlu lebih dikuatkan lagi terutama menyangkut Pembinaan UMKM. Bila Pelaku UMKM tidak diperhatikan dalam kebijakan Pemerintah Daerah akan sangat besar dampaknya pada kemunduran daya saing UMKM di Kabupaten Subang. Bila kebijakan tersebut tidak berpihak dalam membangun Usaha Mikro, Kecil dan Menengah (UMKM) di Kabupaten Subang akan sulit visi dan misi Bupati diwujudkan dalam gelora Jawara Niaga.

Dengan memperhatikan tantangan dan sasaran pembinaan UMKM ke depan dan merujuk pada arah kebijakan nasional, maka kebijakan yang dilaksanakan pemerintah daerah untuk pembinaan UMKM diarahkan untuk meningkatkan produktivitas, kelayakan dan nilai tambah Koperasi dan UMKM sehingga mampu tumbuh ke skala yang lebih besar dan berdaya saing. Arah kebijakan peningkatan kualitas sumber daya manusia dilaksanakan melalui beberapa langkah strategis untuk meningkatkan daya saing UMKM sebagai berikut Peningkatan kapasitas UMKM di daerah melalui Pembinaan yang melibatkan stakeholder yaitu Pemda, pengusaha dan akademisi untuk meningkatkan daya saing UMKM. Meningkatkan jiwa entrepreneurship dengan usaha yang profitable dan sustainable. Penguatan UMKM difokuskan pada peningkatan kinerja dan daya saing UMKM sebagai pencapaian sasaran kinerja melalui program, kegiatan dan output harus dilaksanakan melalui keterpaduan dan kerjasama dalam proses perencanaan, pelaksanaan, data dan informasi. Pelaksanaan program harus bersifat inklusif yang memperhatikan akses dan kesempatan yang sama antar UMKM. Pelaksanaan program dan kegiatan didukung kemitraan dan kerjasama strategis dengan kerjasama bilateral dan multilateral yang didasarkan pada prinsip simbiosis mutualisme. 




Volume 2 Issue 2, Desember 2020

https://ejournal.unsub.ac.id/index.php/bisnis

Ada beberapa fenomena permasalahan yang ditemukan dilapangan terkait dengan Implementasi kebijakan pembinaan UMKM di Kabupaten Subang sebagai berikut :

1. Kepentingan kelompok saasaran dalam kegiatan pembinaan yang dilakukan oleh pemerintah dalam bentuk pelatihan terhadap UMKM masih terbatas dan belum mencapai sasaran dalam meningkatkan kemamapuan manajerial usaha UMKM di Kabupaten Subang.

2. Pelaksanaan Program oleh kebijakan pemerintah daerah dalam meningkatkan bisnis UMKM dalam bentuk permodalam masih kurang atau terbatas sehingga UMKM banyak yang terlibat lintah darat (diantara pengaruh bank emok).

3. Kepatuhan dan daya tanggap pelaku UMKM dalam membangun Usaha Mikro, Kecil dan Menengah (UMKM) di Kabupaten Subang, terutama menyangkut Pembinaan Program UMKM. Perlu diperhatikan dalam pelaksanaannya karena berdampak pada kemajuan UMKM.

4. Sumber daya yang dilibatkan dalam pelatihan pelaku UMKM belum merata, sehingga belum maksimal dimanfaatkan oleh pelaku UMKM.

\section{Kerangka Teori}

Pengembangan Usaha Mikro Kecil dan Menengah (UMKM) dapat definisikan sebagai upaya yang dilakukan oleh pemerintah, dunia usaha dan masyarakat melalui pemberian bimbingan dan bantuan perkuatan untuk menumbuhkan dan meningkatkan kemampuan Usaha Mikro Kecil dan Menengah (UMKM) agar menjadi usaha industri yang tangguh dan mandiri. Jadi dalam hal ini, karena skala usahanya yang masih kecil dan menengah, maka Usaha Mikro Kecil dan Menengah (UMKM) perlu dibimbing dan dibantu oleh setiap stakeholder, khususnya pemerintah. Hal ini seperti yang dikemukakan oleh Ikuro Yamamoto (dalam artikel Zulkieflimansyah (www.zulkieflimansyah.com).

Menurut Sumodiningrat (1999:134), mengatakan bahwa kebijaksanaan pemberdayaan masyarakat secara umum dapat dipilah dalam tiga kelompok yaitu: pertama, kebijaksanaan yang secara tidak langsung mengarah pada sasaran tetapi memberikan dasar tercapainya suasana yang mendukung kegiatan sosial ekonomi masyarakat. Kedua, kebijaksanaan yang secara langsung mengarah pada peningkatan kegiatan ekonomi kelompok sasaran. Ketiga, kebijaksanaan khusus yang menjangkau masyarakat miskin melalui upaya khusus. Pelaksanaan pemberdayaan masyarakat, menurut Kartasasmita (1996:159-160), harus dilakukan melalui beberapa kegiatan: pertama, menciptakan suasana atau iklim yang memungkinkan potensi berkembang (enabling). kedua, memperkuat potensi atau daya yang dimiliki oleh masyarakat (empowering). ketiga, memberdayakan mengandung pula arti melindungi. Di sinilah letak titik tolaknya yaitu bahwa pengenalan setiap manusia, setiap anggota masyarakat, memiliki suatu potensi yang selalu dapat terus dikembangkan. Artinya, tidak ada masyarakat yang sama sekali tidak berdaya, karena kalau demikian akan mudah punah. Pemberdayaan merupakan suatu yang harus diikuti dengan tetap memperkuat potensi atau daya yang dimiliki oleh setiap masyarakat.

Dalam pengembangan pemasaran produk UMKM menjadi penting eksistensi Sumber Daya arena akan menentukan Sistem Produksi UMKM. Unsur pokok dari sistem produksi suatu negara menurut Smith ada tiga, yaitu: 1) Sumber daya alam yang tersedia; 2) Sumber daya insani (jumlah penduduk); 3) Stok barang modal yang ada. 


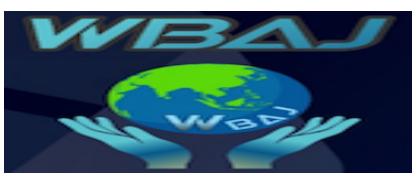

Volume 2 Issue 2, Desember 2020

https://ejournal.unsub.ac.id/index.php/bisnis

Daya saing daerah saat ini menjadi salah satu isu utama dalam pembangunan daerah. Konsep daya saing umumnya dikaitkan dengan kemampuan suatu perusahaan, kota, daerah, wilayah atau negara dalam mempertahankan atau meningkatkan keunggulan kompetitif secara berkelanjutan (Porter, 2000). Salah satu pendekatan yang digunakan untuk memperjelas konsep daya saing daerah adalah berdasarkan definisi European Commision (1999), yang mendefinisikan sebagai berikut: "Kemampuan untuk memproduksi barang dan jasa yang sesuai dengan kebutuhan pasar internasional diiringi oleh kemampuan mempertahankan pendapatan yang tinggi dan berkelanjutan, lebih umumnya adalah kemampuan wilayah untuk menciptakan pendapatan dan kesempatan kerja yang relatif tinggi yang terlihat pada daya saing eksternal" (European Commision, 1999 dalam Gardiner, 2003).

Daya saing UMKM atau kemampuan bersaing UMKM suatu daerah terwujud apabila daerah tersebut memiliki kompetensi inti (core competence) yang dapat dibedakan dari daerah lainnya. Kompetensi inti ini dapat diraih melalui creation of factor, yaitu menciptakan berbagai faktor produksi yang jauh lebih baik dibandingkan para pesaingnya, sehingga suatu daerah mampu memiliki produk yang tinggi dari aspek competitive advantage.

Kompetensi inti dalam konteks pembangunan ekonomi wilayah merupakan upaya dalam mengkoordinasikan dan mengintegrasikan sektor-sektor ekonomi yang berkembang di wilayah/daerah tertentu. Semakin baik koordinasi dan integrasi yang terwujud, maka akan semakin tinggi pula upaya penciptaan kompetensi inti, yang berimplikasi pada sulitnya wilayah/daerah lain untuk bersaing.

Dalam konteks otonomi daerah, maka saat ini dan masa mendatang keberhasilan pengembangan ekonomi wilayah/daerah sangat tergantung pada kebijakan pemerintah daerah setempat, terutama dalam menyikapi perubahanperubahan yang terjadi. Oleh karena itu, setiap pemerintah daerah dewasa ini dituntut untuk mampu mengembangkan visi sesuai dengan nilai, arah dan tujuan yang akan mengarahkan masa depan wilayah yang bersangkutan.

Komoditas unggulan adalah produk potensial yang dipandang dapat dipersaingkan dengan produk sejenis di daerah lain, karena disamping memiliki keunggulan komparatif juga memiliki efesiensi usaha yang tinggi (Tambunan, 2001). Komoditas unggulan merupakan hasil usaha masyarakat yang memiliki peluang pemasaran yang tinggi dan menguntungkan bagi masyarakat. Hal ini dikarenakan pada komoditas unggulan tersebut terdapat sejumlah kriteria, yaitu:

(1). Mampu menjadi penggerak utama (prime mover) pembangunan perekonomian. Dengan kata lain, komoditas unggulan tersebut dapat memberikan kontribusi yang signifikan pada peningkatan produksi, pendapatan dan pengeluaran. Misalnya, cengkeh di Sulawesi Utara, kakao di Sulawesi Tenggara, minyak dan gas bumi di Nangroe Aceh Darussalam, serta pariwisata di Bali; (2). Mempunyai keterkaitan ke depan dan ke belakang (forward and backward linkages) yang kuat, baik sesama komoditas unggulan maupun komoditas lainnya; (3). Mampu bersaing dengan produk sejenis dari wilayah lain (competitiveness) di pasar nasional dan pasar internasional, baik dalam harga produk, biaya produksi dan kualitas pelayanan; (4). Memiliki keterkaitan dengan wilayah lain (regional linkages), baik dalam hal pasar (konsumen) maupun pemasokan bahan baku; (5).Memiliki status teknologi (state of the art) yang terus meningkat, terutama melalui inovasi teknologi; (6). Mampu menyerap tenaga kerja berkualitas secara optimal sesuai dengan skala produksinya; (7). Dapat 
bertahan dalam jangka panjang tertentu, mulai dari fase kelahiran (increasing), pertumbuhan (growth) hingga fase kejenuhan (maturity) atau penurunan (decreasing). Jika komoditas unggulan yang satu memasuki tahap kejenuhan atau penurunan maka komoditas unggulan lainnya harus mampu menggantikannya; (8). Tidak rentan terhadap gejolak eksernal dan internal; (9). Pengembangannya harus mendapatkan berbagai bentuk dukungan, misalnya keamanan, sosial, budaya, informasi dan peluang pasar, kelembagaan, fasilitas insentif/ disinsentif dan lain-lain; serta (10). Pengembangannya berorientasi pada kelestarian sumber daya dan lingkungan (Daryanto dan Hafizrianda, $2010: 31$ - 32).

Implementasi kebijakan pada prinsipnya adalah cara agar sebuah kebijakan dapat mencapai tujuan. Untuk mengimplementasikan kebijakan publik, maka ada dua pilihan langkah yang ada, yaitu langsung mengimplementasikan dalam bentuk program-program atau melalui formulasi kebijakan derivat atau turunan dari kebijakan publik tersebut (Nugroho, 2004 : 158). Implementasi kebijakan adalah bagian dari rangkaian proses kebijakan publik. Proses kebijakan adalah suatu rangkaian tahap yang saling bergantung yang diatur menurut urutan waktu: penyusunan agenda, formulasi kebijakan, adopsi kebijakan, dan penilaian kebijakan (Winarno, 2008 : 29). Teori Merilee S. Grindle dalam (Subarsono, 2010: 93) menyebutkan Keberhasilan implementasi menurut Merilee S. Grindle (1980) dipengaruhi oleh dua variabel besar, yakni

1. Isi kebijakan (content of policy)

a) Kepentingan kelompok sasaran;

b) Tipe manfaat;

c) Derajat perubahan yang diinginkan;

d) Letak pengambilan keputusan.

e) Pelaksanaan program;

f) g. Sumberdaya yang dilibatkan.

2. Lingkungan Implementasi (context of implementation)

a) Kekuasaan, kepentingan, dan strategi aktor yang terlibat;

b) Karakteristik lembaga dan penguasan;

c) Kepatuhan dan daya tangkap

\section{Metode Penelitian}

Pendekatan yang akan dipakai dalam penelitian ini adalah penelitian kualitatif. Adapun yang dimaksud dengan metode penelitian kualitatif seperti yang didefinisikan oleh Creswell (2010:4) menyatakan penelitian kualitatif merupakan metode-metode untuk mengeksplorasi dan memahami makna yang oleh sejumlah individu atau kelompok orang dianggap berasal dari masalah sosial atau kemanusiaan. Proses penelitian ini melibatkan upaya-upaya penting seperti mengajukan pertanyaan-pertanyaan dan prosedur-prosedur mengumpulkan data spesifik dari partisipan, menganalisis data secara induktif melalui tema-tema yang khusus ke tema-tema yang umum, dan menafsirkan makna dari data.

Tujuan utama penelitian kualitatif adalah untuk memahami (to understand) fenomena atau gejala sosial dengan lebih menitik beratkan pada gambaran yang lengkap tentang fenomena yang dikaji daripada memerincinya menjadi variabelvariabel yang saling 


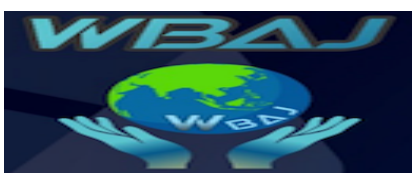

Volume 2 Issue 2, Desember 2020

https://ejournal.unsub.ac.id/index.php/bisnis

terkait. Harapannya ialah diperoleh pemahaman yang mendalam tentang fenomena untuk selanjutnya dihasilkan sebuah teori. Karena tujuannya berbeda dengan penelitian kuantitatif, maka prosedur perolehan data dan jenis penelitian kualitatif juga berbeda. Selanjutnya, Sugiyono (2007:1), mendefinisikan metode penelitian kualitatif sebagai metode penelitian yang digunakan untuk meneliti pada kondisi objek yang alamiah, (sebagai lawannya adalah eksperimen) dimana peneliti adalah sebagai instrumen kunci, teknik pengumpulan data dilakukan secara triangulasi (gabungan), analisis data bersifat induktif dan penelitian kualitatif lebih menekankan makna dari pada generalisasi. Objek dalam penelitian kualitatif adalah objek yang alamiah, atau natural setting, sehingga metode penelitian ini sering disebut sebagai metode naturalistik. Objek yang alamiah adalah objek yang apa adanya, tidak manipulasi oleh peneliti.

\section{Hasil dan Pembahasan}

UMKM adalah singkatan dari Usaha Mikro Kecil dan Menengah. UMKM diatur berdasarkan Undang-Undang Nomor 20 tahun 2008 tentang Usaha Mikro Kecil dan Menengah. Berikut ini adalah ilustrasi dari isi Undang Undang Nomor 20 tahun 2008.

1. Usaha Mikro Berdasarkan Undang Undang Nomor 20 Tahun 2008 tentang

2. UMKM (Usaha Menengah Kecil dan Mikro) adalah usaha produktif milik

3. orang perorangan dan / atau badan usaha perorangan yang memenuhi kriteria Usaha Mikro sebagaimana diatur dalam Undang-Undang ini.

4. Usaha Kecil adalah usaha ekonomi produktif yang berdiri sendiri, yang dilakukan oleh orang perorangan atau badan usaha yang bukan merupakan anak perusahaan atau bukan cabang perusahaan yang dimiliki, dikuasai, atau menjadi bagian baik langsung maupun tidak langsung dari usaha menengah atau usaha besar yang memenuhi kriteria Usaha Kecil sebagaimana dimaksud dalam Undang-Undang ini.

5. Usaha Menengah adalah usaha ekonomi produktif yang berdiri sendiri, yang dilakukan oleh orang perseorangan atau badan usaha yang bukan merupakan anak perusahaan atau cabang perusahaan yang dimiliki, dikuasai, atau menjadi bagian baik langsung maupun tidak langsung dengan Usaha Kecil atau usaha besar dengan jumlah kekayaan bersih atau hasil penjualan tahunan sebagaimana diatur dalam Undang-Undang ini.

6. Usaha mikro merupakan kegiatan usaha yang dapat memperluas lapangan pekerjaan serta memberikan pelayanan ekonomi secara luas kepada masyarakat dan dapat berperan dalam proses pemerataan dan peningkatan pendapatan masyarakat, mendorong pertumbuhan ekonomi, serta berperan mewujudkan stabilitas nasional. Selain itu, usaha mikro adalah salah satu pilar utama ekonomi nasional yang medapatkan kesempatan utama, dukungan, perlindungan serta pengembangan yang secara luas sebagai wujud pihak yang tegas kepada kelompok usaha ekonomi rakyat, tanpa harus mengabaikan peranan usaha besar dan badan usaha milik pemerintah.

7. Menurut Departemen Tenaga Kerja (Depnaker) usaha mikro adalah usaha yang memiliki kurang dari 5 orang tenaga kerja.

Terdapat beberapa acuan definisi yang digunakan berbagai instansi di Indonesia, yaitu: UU no.9 tahun 1995 tentang mengatur kriteria usaha kecil berdasarkan nilai aset tetap 


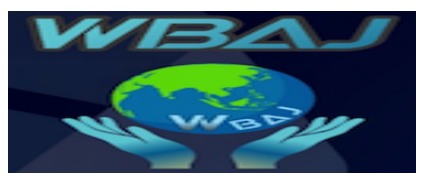

Volume 2 Issue 2, Desember 2020

https://ejournal.unsub.ac.id/index.php/bisnis

(di luar tanah dan bangunan) paling besar Rp 200 juta dengan omzet per tahun maksimal Rp 1 milyar. Sementara itu berdasarkan Inpres No.10 tahun 1999 tentang usaha menengah, batasan aset tetap (di luar tanah dan bangunan) untuk usaha menengah adalah Rp 200 juta hingga Rp 10 milyar.

Kementrian Koperasi dan UKM menggolongkan suatu usaha sebagai usaha kecil jika memiliki omset kurang dari Rp 1 milyar per tahun. Untuk usaha menengah batasannya adalah usaha yang memiliki omset antara Rp 1 sampai dengan Rp 50 milyar per tahun. Departemen Perindustrian dan Perdagangan menetapkan bahwa industri kecil dan menengah adalah industri yang memiliki nilai investasi sampai dengan $\mathrm{Rp} 5$ milyar. Sementara itu usaha kecil di bidang perdagangan dan industri juga dikategorikan sebagai usaha yang memiliki aset tetap kurang dari Rp 200 juta dan omzet per tahun kurang dari Rp 1 milyar (sesuai UU no.9 tahun 1995)

Bank Indonesia menggolongkan usaha kecil dengan merujuk pada UU no 9/1995, sedangkan untuk usaha menengah BI menentukan sendiri kriteria aset tetapnya dengan besaran yang dibedakan antara industri manufaktur (Rp 200 juta s/d Rp 5 miliar) dan non manufaktur (Rp 200 - 60 juta). Implementasi sebagai suatu proses tindakan administrasi dan politik. Pandangan ini sejalan dengan pendapat Peter S. Cleaves (dalam Solichin Abdul Wahab 2008:187), dengan tegas menyebutkan bahwa implementasi itu mencakup "a process of moving toward a policy objective by means of administrative and political steps" secara garis besar, beliau mengatakan bahwa fungsi implementasi itu ialah untuk membentuk suatu hubungan yang memungkinkan tujuan-tujuan ataupun sasaran-sasaran kebijakan publik diwujudkan sebagai outcomes hasil akhir kegiatan yang dilakukan oleh pemerintah: Implementasi kebijakan merupakan aspek yang sangat penting di dalam seluruh proses kebijakan karena kebijakan publik yang telah dibuat akan bermanfaat bila diimplementasikan. Suatu program kebijakan harus diimplementasikan agar mempunyai dampak atau tujuan yang diinginkan. Implementasi kebijaksanaan menurut kamus Webster dalam Wahab (2004:64), merumuskan secara pendek bahwa "to implement"

("Mengimplementasikan") berarti "to provide the means of carrying out" ("Menyediakan sarana untuk melaksanakan sesuatu"), "to give practical effect to" ("Menimbulkan dampak atau akibat terhadap sesuatu"). Pengertian tersebut mempunyai arti bahwa dalam mengimplementasikan sesuatu harus menyediakan sarana yang mendukung agar dalam pelaksanaan sesuatu tersebut menimbulkan dampak atau akibat.

Mazmania dan Sabatier dalam Rusli (2013:87), mendefinisikan implementasi kebijakan sebagai:

"Pelaksanaan keputusan kebijakan dasar, biasanya dalam bentuk undangundang, namun dapat pula dalam bentuk perintah-perintah atau keputusankeputusan eksekutif yang penting atau keputusan badan peradilan. Lazimnya, keputusan tersebut mendefinisikan masalah yang ingin di atasi, menyebutkan secara tegas tujuan atau saran yang ingin dicapai, dan berbagai cara untuk menstrukturkan atau mengatur proses implementasinya".

Menurut Van Meter dan Van Horn dalam Rusli (2013:86) menyatakan bahwa implementasi kebijakan sebagai berikut: “Tindakan-tindakan yang dilakukan oleh individu, umum atau pribadi (atau kelompok) yang di arahkan untuk mencapai tujuan-tujuan yang telah ditetapkan dalam keputusan-keputusan kebijakan sebelumnya". 


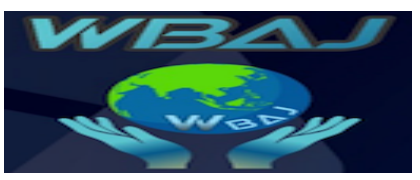

Volume 2 Issue 2, Desember 2020

https://ejournal.unsub.ac.id/index.php/bisnis

Dalam perspektif ini, bagi para pelaksananya, implementasi kegiatan atau program harus dipahami dan kemudian dinilai dari hasil yang diraih setelah sebuah program atau kebijakan itu dilaksanakan. Pemahaman tersebut tidak berhenti setelah pelaksana melakukan kegiatan untuk mencapai tujuan, tetapi terus berlanjut hingga dicapainya sebuah tujuan yang ditetapkan. (Rusli, 2013:84).

Proses implementasi kebijakan baru dapat dimulai setelah undang-undang kebijakan publik telah ditetapkan, program-program telah dibuat, dan dana telah di alokasikan untuk pencapaian tujuan kebijakan tersebut. Hal senada seperti yang dinyatakan Sunggono (1994:137), bahwa implementasi kebijakan merupakan suatu upaya untuk mencapai tujuan-tujuan tertentu dengan sarana tertentu. Secara konkrit misalnya dapat kita lihat secara sederhana antara lain jumlah dan isi barang dan jasa yang dihasilkan pemerintah dalam jangka waktu tertentu untuk meningkatkan taraf kesejahteraan warga masyarakat.

Perubahan taraf kesejahteraan masyarakat dianggap sebagai hasil akhir kebijakan yang disebut juga sebagai "policy income" atau "policy impact". Dengan sendirinya didalam hasil akhir kebijakan, kebijakan termasuk juga hasil sampingan disamping "policy performance" yang diperoleh.

Menurut Teori Implementasi Kebijakan Edwards III dalam Winarno (2007:174) menjelaskan bahwa implementasi kebijakan sebagai berikut:

"Tahap pembuatan kebijakan antara pembentukan kebijakan dan konsekuensikonsekuensi kebijakan bagi masyarakat yang dipengaruhinya. Jika suatu kebijakan tidak tepat atau tidak dapat mengurangi suatu masalah yang merupakan sasaran kebijakan, maka kebijakan tersebut sangat mungkin mengalami kegagalan walaupun kebijakan tersebut diimplementasikan dengan sangat baik. Sebaliknya suatu kebijakan yang di anggap baik juga akan mengalami kegagalan jika tidak diimplementasikan dengan baik oleh para pelaksana kebijakan".

Seberapa baiknya suatu kebijakan kalau tidak dipersiapkan dan direncanakan dengan baik implementasinya maka apa yang menjadi tujuan kebijakan publik tidak akan terwujud. Begitu pula sebaliknya, sebaik apapun persiapan dan perencanaan implementasi kebijakan apabila tidak diimplementasikan dengan baik oleh para pelaksana kebijakan apa yang menjadi tujuan kebijakan maka tidak bisa tercapai.

Menurut Grindle dalam Rusli (2013:95) ada sejumlah persamaan mendasar dari berbagai model implementasi yang ditawarkan oleh sejumlah ahli dalam membedah persoalan implementasi kebijakan dalam mencapai tujuannya. Secara umum, dalam proses implementasi sebuah kebijakan, para ahli mengidentifikasi berbagai faktor yang mempengaruhi keberhasilan implementasi sebuah kebijakan. Dari kumpulan faktor tersebut setidaknya ada tiga faktor utama yang sering disebut, meskipun dengan titik tekan yang berbeda-beda. Ketiga faktor tersebut adalah:

1. Isi atau content kebijakan. Kebijakan yang baik dari sisi content setidaknya mempunyai sifat-sifat sebagai berikut : jelas, tidak distarsif, didukung oleh dasar teori yang teruji, mudah dikomunikasikan ke kelompok target, didukung oleh sumber daya baik manusia maupun finansial yang baik.

2. Implementor atau pelaksana kebijakan dan kelompok target. Pelaksanaan implementasi kebijakan tergantung pada badan pelaksana kebijakan (implementor) dan kelompok target (target groups). Implementor harus 
mempunyai kapabilitas, kompetensi, komitmen dan konsistensi untuk melaksanakan sebuah kebijakan sesuai dengan arahan dari penentu kebijakan (policy makers). Selain itu, kelompok target yang terdidik dan relatif homogen akan lebih mudah menerima sebuah kebijakan daripada kelompok yang tertutup, tradisional dan heterogen. Lebih lanjut, kelompok target yang merupakan bagian besar dari populasi juga akan lebih mempersulit keberhasilan implementasi kebijakan.

3. Lingkungan. Keadaan sosial-ekonomi, politik, dukungan publik maupun kultur populasi tempat sebuah kebijakan diimplementasikan juga akan

mempengaruhi keberhasilan kebijakan publik. Kondisi sosial-ekonomi sebuah masyarakat yang maju, sistem politik yang stabil dan demokratis, dukungan baik dari konstituen maupun elit penguasa, dan budaya keseharian masyarakat yang mendukung akan mempermudah implementasi sebuah kebijakan.

Ketiga hal tersebut yang menjadi benang merah diantara para ahli terkait sejumlah faktor yang mempengaruhi proses implementasi kebijakan dalam mencapai tujuannya. Barangkali yang berbeda diantara sejumlah ahli adalah mengenai bagaimana model itu dirumuskan menjadi sesuatu yang mudah diterima oleh penggunanya, termasuk oleh orang yang paling awam sekalipun. Bukan tingkat kerumitan atau kecanggihannya yang membuat ia digunakan dan menjadi pilihan sebagai acuan dalam melihat proses implementasi kebijakan. Justru karena kesederhanaannya yang menjadikannya menarik digunakan sebagai acuan. Meskipun sederhana, tidak berarti ia dibuat asal-asalan, dan beberapa sudah terbukti akurasinya dalam mendekati sebuah persoalan implementasi kebijakan.

Dalam suatu kebijakan perlu dipertimbangkan pula kekuatan dan kekuasaan, kepentingan serta strategi yang digunakan oleh para aktor yang terlibat guna memperlancar jalannya pelaksanaan suatu implementasi kebijakan. Bila ini tidak diperhitungkan dengan matang, sangat besar kemungkinan program yang hendak diimplementasikan akan jauh hasilnya dari yang diharapkan.

a. Kekuasaan, kepentingan, dan strategi

Pemerintah harus lebih ditingkatkan dalam pembinaan UMKM

b. Karakteristik Lembaga dan penguasaan

Karakteristik dari suatu Lembaga akan turut mempengaruhi suatu kebijakan, persoalannya dalam hal ini belum jelasnya karakteristik institusi dan rezim yang sedang berkuasa.

c. Kepatuhan dan daya tanggap

Hal yang dirasa penting dalam proses pelaksanaan suatu kebijakan adalah kepatuhan dan respon dari para pelaksana pembinaan UMKM. Tingkat kepatuhan dan responsivitas UMKM masih perlu diperhatikan.

\section{Isi kebijakan (content of policy)}

Kebijakan yang baik dari sisi content setidaknya mempunyai sifat-sifat sebagai berikut : jelas, tidak distarsif, didukung oleh dasar teori yang teruji, mudah dikomunikasikan ke kelompok target, didukung oleh sumber daya baik manusia maupun finansial yang baik.

Kebijakan publik merupakan suatu formulasi, implementasi dan evaluasi kebijakan yang berkesinambungan dan saling terkait, yang dilakukan oleh pemerintah dengan skateholders dalam mengatur, mengelola dan menyelesaikan berbagai urusan publik, 


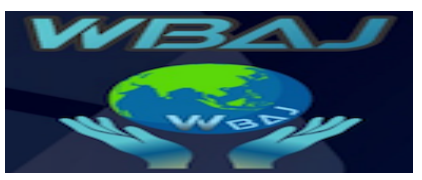

Volume 2 Issue 2, Desember 2020

https://ejournal.unsub.ac.id/index.php/bisnis

masalah publik dan sumberdaya yang ada untuk kemasalahatan publik. Dari ketiga proses tersebut, tahapan implementasi dan evaluasi kebijakan publik merupakan hal yang penting dilakukan. Implementasi kebijakan pada prinsipnya adalah cara agar sebuah kebijakan dapat mencapai tujuannya. Implementasi kebijakan adalah hal yang paling berat, karena disini masalah-masalah yang kadang tidak dijumpai dalam konsep, muncul dilapangan.

\section{a) Kepentingan Kelompok Sasaran}

Terkait dengan kepentingan kelompok sasaran dalam isi kebijakan Pembinaan UMKM Pada Dinas Koperasi, UMKM Perdagangan dan Perindustrian Kabupaten Subang, peneliti melakukan wawancara dengan Kepala Dinas koperasi UMKM, Perdagangan, dan perindustrian Kabupaten Subang, Bapak Drs.H. Rahmat Fatharrahman, M.Si. Beliau mengatakan bahwa kepentingan kelompok sasaran Dinas Koperasi, UMKM Perdagangan Dan Perindustrian Kabupaten Subang belum efektif dan perlu ditingkatkan, berikut petikan wawancaranya :

“Kepentingan Kelompok Sasaran belum efektif, termasuk dalam mendukung program Musyawarah Rencana Pembangunann

(MUSRENBANG) hal ini sesuai degan aturan kepala daerah termasuk arahan dari bupati kabupaten subang untuk meningkatkan sektor UMKM wilayah kabupaten subang, dalam hal ini kebijakan harus tepat sasaran dan tidak ada kepentingan kelompok sasaran karena beberapa produk UMKM sudah masuk pasar internasional hal ini perlu ditingkatkan lagi agar menjadi acuan untuk UMKM lainnya yang ada di Kabupaten Subang".

Hal yang sama juga masih diungkapkan oleh kepala bidang UMKM Dinas Koperasi, UMKM Perdagangan dan Perindustrian Kabupaten Subang yang mengatakan kepada peneliti bahwa sudah efektif berjalan dengan baik, karena semua aspek dalam meningkatkan sektor UMKM terjalankan dengan baik dantidak adanya Kepentingan Kelompok Sasaran, berikut pernyataan beliau :

"kepentingan kelompok sasaran semua sama rata akan tetapi dikelompokan sesuai dengan sektor pada produk UMKM nya itu sendiri hal ini untuk memudahkan penentuan implementasi kebijakan yang tepat terhadap UMKM itu sendiri, agar dapat meningkat kualitas dan kuantitas produk pada tiap UMKM".

\section{b) Tipe Manfaat}

Berdasarkan hasil wawancara yang diungkapkan oleh Kepala Dinas koperasi UMKM, Perdagangan, dan perindustrian Kabupaten Subang, mengatakan kepada peneliti bahwa Tipe Manfaat pada isi kebijakan sudah berjalan dengan baik, karena isi kebijakan dapat terjalankan, berikut pernyataan beliau :

“ada beberapa program Musyawarah Rencana Pembangunann dalam meningkatkan UMKM misalnya, adek liat saja tuh di luar banyak sekali produk UMKM yang bermunculan dan menarik perhatian termasuk dari manfaat pelatihan UMKM pemasarannya dan daya saing terhadap produk-produk yang ada di pasaran. Hal ini bertujuan agar pihak UMKM dapat menerima manfaat dari program musrenbang ini, dan Dinas koperasi UMKM, Perdagangan, dan perindustrian Kabupaten 


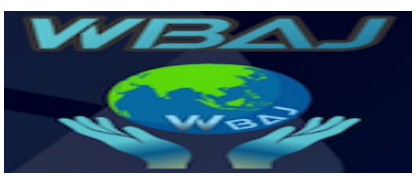

Volume 2 Issue 2, Desember 2020

https:/ / ejournal.unsub.ac.id/index.php/bisnis

Subang. Mampu bekerja dengan baik terhadap pelaku UMKM itu sendiri. Agar tipe manfaat ini dapat dirasakan langsung oleh pelaku UMKM itu sendiri".

Tercermin bahwa memang Tipe Manfaat pada isi kebijakan sudah berjalan dengan baik. Pada saat peneliti melakukan wawancara dengan pelaku UMKM itu sendiri agar tipe manfaat dari isi kebijakan tetap sasaran. berikut pernyataan beliau :

"adanya bantuan fasilitas bagi setiap pelaku UMKM hal ini dapat membantu kemajuan, kami selaku pelaku usaha, melalui beberapa pelatihan dan pembinaan yang di lakukan oleh dinas yang terkait hal ini berdampak dari tingkat daya beli dan pegelolaan, hal ini saya harap dapat lebih di tingkatkan lagi kedepannya".

\section{c) Derajat Perubahan Yang Diinginkan}

Berdasarkan hasil wawancara yang diungkapkan oleh Kepala Dinas koperasi UMKM, Perdagangan, dan perindustrian Kabupaten Subang, mengatakan kepada peneliti bahwa Derajat perubahan yang diinginkan pada isi kebijakan sudah berjalan dengan baik, karena isi kebijakan yang dapat terjalankan, berikut pernyataan beliau

"ada beberapa program Musyawarah Rencana Pembangunann (MUSRENBANG) dalam meningkatkan UMKM yang memberi derajat perubahan pada pelaku UMKM perubahan ini dapat terjadi atas Kerjasama yang baik pada semua pihak baik dari DKUPP Kabupaten

Subang dan Pelaku UMKM. Seperti adanya pelatihan dan pembinaan serta pameran UMKM hal ini agar daya beli masyarakat meningkat. Bahkan diera digital ini banyak sekali promosi yang dilakukan melalui media sosial oleh pelaku usaha, sehingga DKUPP memberi BIMTEK kepada pelaku UMKM itu sendiri. Derajat perubahan yang diingkan ini harus dibarengi dengan peningkatan kemampuan para pelaku UMKM".

\section{d) Letak Pengambilan Keputusan}

Peneliti mencoba menanyakan kepada Kepala Dinas koperasi UMKM,

Perdagangan, dan perindustrian Kabupaten Subang, mengatakan kepada peneliti bahwa letak pengambilan keputusan yang diinginkan pada isi kebijakan sudah berjalan dengan baik, karena isi kebijakan dalam pengambilan keputusan sudah tepat, berikut petikan wawancaranya :

"letak pengambilan keputusan sangat penting hal ini harus seusai dengan kebijakan yang ada pada sektor UMKM yang diperlukan, mengacu pada MUSRENBANG pengambilan keputusan harus tepat sasaran, karena tidak sembarangan dalam pengambilan keputusa, begitupun dalam halnya menjalankan program mengawasi dan mengevaluasi dari letak pengambilan keputusan itu sendiri yang telah saya lakukan dan memerintahkan jajaran untuk kepentingan bersama memajukan sektor UMKM ini, khususnya dalam mendukung program, karna kan program itu dibentuk dan disahkan melalui hasil rapat-rapat, tetapi untuk kedepannya akan kita coba untuk tingkatkan". 
Kepala Bagian mengatakan letak pengambilan keputusan yang diinginkan pada isi kebijakan sudah berjalan dengan baik, karena isi kebijakan dalam pengambilan keputusan sudah tepat, berikut petikan wawancaranya :

"sesuai dengan pendapat dari kepala dinas DKUPP, saya selalu berkoordinasi mengenai apa saja yang akan menjadi pengambilan keputusan itu sendiri terutama dari sektor UMKM, hal ini agar pengambilan keputusan menjadi efektif"

\section{e) Pelaksanaan Program}

Berdasarkan hasil wawancara yang diungkapkan oleh Kepala Dinas koperasi UMKM, Perdagangan, dan perindustrian Kabupaten Subang, mengatakan kepada peneliti bahwa pelaksanaan program yang diinginkan pada isi kebijakan sudah berjalan dengan efektif, karena isi kebijakan yang dapat terjalankan, berikut pernyataan beliau :

"dalam pelaksanaan program, semua telah disusun sesuai dengan MUSRENBANG, dari hal ini terdapat program unggulan atau prioritas agar menjadikan program lebih tersusun, bahkan program yang di susun dan dilaksanakan sesuai dengan penetapan potensi daerah agar semua ini memajukan sektor UMKM ini, khususnya dalam mendukung program, karena program itu dibentuk dan disahkan melalui hasil rapatrapat, tetapi untuk kedepannya akan kita coba untuk tingkatkan".

Kepala Bagian mengatakan letak pengambilan keputusan yang diinginkan pada isi kebijakan sudah berjalan dengan baik, karena isi kebijakan dalam pengambilan keputusan sudah tepat, berikut petikan wawancaranya :

"sesuai dengan pendapat dari kepala dinas DKUPP, saya selalu berkoordinasi mengenai apa saja yang akan menjadi pengambilan keputusan itu sendiri terutama dari sektor UMKM, hal ini agar pengambilan keputusan menjadi efektif"

\section{f) Sumber Daya Yang Dilibatkan}

Berdasarkan hasil wawancara yang diungkapkan oleh Kepala Dinas koperasi UMKM, Perdagangan, dan perindustrian Kabupaten Subang, Bapak mengatakan kepada peneliti bahwa sumber daya yang dilibatkan pada isi kebijakan sudah berjalan dengan baik atau efektif, karena isi kebijakan yang dapat terjalankan, berikut pernyataan beliau :

"Adapun sumberdaya yang dilibatkan dalam setiap program biasanya seperti pemerintah daerah, pelaku UMKM dan stakeholder yang terikat dengan program yang akan di jalankan hal ini agar semua saling sinergi dan saling menukung kemajuan sektor UMKM".

Kepala Bagian mengatakan sumber daya yang dilibatkan pada isi kebijakan sudah berjalan dengan baik, karena isi kebijakan dalam pengambilan keputusan sudah tepat, 
berikut petikan wawancaranya :

"dari beberapa pihak yang terlibat, perlu diketahui semuanya sesuai peran dan fungsi masing masing yang akan di jalankan. Seperti halnya terus menjalin Kerjasama yang baik dalam pengadaan akses bantuan teknologi lainnya"

\section{Lingkungan Implementasi (context of implementation)}

Lingkungan Implementasi (context of implementation) Keadaan sosialekonomi, politik, dukungan publik maupun kultur populasi tempat sebuah kebijakan diimplementasikan juga akan mempengaruhi keberhasilan kebijakan publik. Kondisi sosial-ekonomi sebuah masyarakat yang maju, sistem politik yang stabil dan demokratis, dukungan baik dari konstituen maupun elit penguasa, dan budaya keseharian masyarakat yang mendukung akan mempermudah implementasi sebuah kebijakan.

\section{a) Kekuasaan, Kepentingan, dan Strategi Aktor Yang Terlibat}

Berdasarkan hasil wawancara yang diungkapkan oleh Kepala Dinas koperasi UMKM, Perdagangan, dan perindustrian Kabupaten Subang, mengatakan kepada peneliti bahwa Kekuasaan, Kepentingan, dan Strategi Aktor Yang Terlibat yang diinginkan pada isi kebijakan belum berjalan dengan baik atau belum efektif, karena isi kebijakan yang dapat terjalankan, berikut pernyataan beliau :

"yang biasanya terlibat kekuasaan, Kepentingan, dan Strategi Aktor Yang Terlibat saling berkaitan hal ini juga di pengaruhi dengan penguasa, sehingga banyak hal yang tertunda karena aktor yang terlibat banyak urusan, maka dari itu selalu diingatkan agar bisa berjalan dengan efektif dan efesien agar tetap sinergi antara kekuasaan dan kepentingan serta aktor yang terlibat dalam kemajuan UMKM ini".

Tidak jauh berbeda dari pernyataan informan sebelumnya, informan lain pun mengungkapkan sebagai berikut:

"memang ada beberapa hal antara kekuasaan dan kepentingan yang kadang kala selalu menjadi halangan karena itu banyak hal yang ketunda tapi ini harus diselesaikan sesuai arahan atau pelaksanaan yang tepat waktu agar semua menjalin koordinasi yang baik,walaupun coba untuk fokus tapi kan ada saja hal kepentingan diatas kepentingan, memang harus diperbaiki secara cepat dan tepat

Dari hasil wawancara, banyak hal yang masih menjadi pekerjaan rumah untuk melaksanakan program, hal ini masih dalam pengerjaan agar sektor UMKM dapat melaksanakan program dengan baik tanpa terganggu dengan kepentingan oleh beberapa aktor, hal ini selalu dikoordinasikan agar implementasi kebijakan yang sudah di buat dapat di laksanakan dengan baik.

\section{b) Karakteristik Lembaga dan Penguasan}

Berdasarkan hasil wawancara yang diungkapkan oleh Kepala Dinas koperasi UMKM, Perdagangan, dan perindustrian Kabupaten Subang, mengatakan kepada 




Volume 2 Issue 2, Desember 2020

https://ejournal.unsub.ac.id/index.php/bisnis

peneliti bahwa Karakteristik Lembaga dan Penguasan yang diinginkan pada isi kebijakan sudah berjalan dengan baik, karena isi kebijakan yang dapat terjalankan, berikut pernyataan beliau :

"menurut saya karakteristik Lembaga dan penguasa biasanya terdiri dari beberapa karakter sesuai dengan SDM nya untuk menyelesaikan kepentingan -kepentingan dari penguasa agar lembaga dapat mewadahi program yang telah disusun dan di laksanakan. Meminimalisir konflik yang ada yang berbeda pendapat. Ketika saya harus bersinergi dengan bawahan saya selalu koordinasi dengan kepala bagian dan pelaku UMKM agar terciptanya Kerjasama yang efektif dan efesien".

Tidak jauh berbeda dari pernyataan informan sebelumnya, informan lain pun mengungkapkan sebagai berikut :

“Karakteristik Lembaga dan Penguasan memiliki wewenang terhadap program dan pelaksanaan program, ssaya selalu berkoordinasi terhadap penguasa terutama kepala dinas dan pemerintah daerah, Ketika terjadi hambatan ataupun pelaksanaan program yang telah dilaksanakan.".

\section{c) Kepatuhan dan Daya Tangkap}

Berdasarkan hasil wawancara yang diungkapkan oleh Kepala Dinas koperasi UMKM, Perdagangan, dan perindustrian Kabupaten Subang, mengatakan kepada peneliti bahwa Kepatuhan dan Daya Tangkap pada isi kebijakan sudah berjalan dengan baik, karena isi kebijakan yang dapat terjalankan, berikut pernyataan beliau :

"Implementor atau orang yang menjalankan implementasi seperti saya harus memiliki kepekaan terhadap kebutuhan-kebutuhan kelompok sasarannya agar program yang diimplementasikan berhasil, pentingnya kepatuhan dan daya tangkap sebuah program agar berhasil, seperti yang dikaji di MUSRENBANG maka pelaksanaannya harus sesuai prosedur patuh akan aturan main yang sudah di sepakati, koordinasi atasan dan bawahan apabila terjadi konflik maka perlunya musyawarah agar dapat solusi yang baik, daya tangkap terhadap program sangat penting untuk mengukur SDM terhadap kinerja dalam sebuah program, hal ini saya selalu berusaha memaksimalkan bantuan bantuan melalui program yang ada dengan kepala bagian dan jajarannya yang ada, terhadap kemajuan UMKM kabupaten subang".

Tidak jauh berbeda dari pernyataan informan sebelumnya, informan lain pun mengungkapkan sebagai berikut:

“untuk sektor UMKM saya selalu berkoordinasi dengan pelaku UMKM agar berjalan lancar, apabila terjadi ketidaktahuan informasi Ketika melaksanakan pelatihan dll, perlu di bimbing agar daya tangkap terhadap suatu program bisa berjalan dengan baik efektif dan efesien".

Kerjasama memang sangat diperlukan demi menghasilkan implementasi kebijakan yang baik dari tiap-tiap pelaku usaha dan pemegang kebijakan, sudah berjalan cukup baik dan ada beberapa hal yang mesti ditingkatkan Kembali. 


\section{Kesimpulan}

Kepentingan Kelompok Sasaran dalam isi kebijakan di Dinas Koperasi, UMKM Perdagangan Dan Perindustrian Kabupaten Subang belum efektif, masih perlu meningkatan dalam mendukung program yang telah disusun dan tidak ada lagi kepentingan yang sehingga tidak tepat sasaran menjadi permasalahan yang dapat mengganggu program yang dilaksanakan. Serta kekuasaan kepentingan dan strategi aktor yang terlibat juga belum efektif sama hal nya dengan kepentingan kelompok sasaran, sesuai dengan hasil wawancara, terdapat beberapa kendalam dalam pelaksanaan program karena terjadi keterlambatan dalam kinerja program, hal ini harus menjadi perbaikan dalam melaksanakan program, agar berjalan dengan efektif. Kemudian dalam dimensi isi kebijakan lainnya, seperti : tipe manfaat, derajat perubahan yang diingkan, letak pengambilan keputusan, pelaksanaan program, sumber daya yang dilibatkan, sudah efektif sesuai dengan wawancara dalam penelitian yang dilakukan di Dinas Koperasi, UMKM Perdagangan Dan Perindustrian Kabupaten Subang. Serta dalam dimensi lingkungan implementasi seperti : karaterristik Lembaga dan penguasaan, kepatuhan dan daya tangkap sudah efektif sesuai dengan wawancara dalam penelitian yang dilakukan di Dinas Koperasi, UMKM Perdagangan Dan Perindustrian Kabupaten Subang.

\section{Referensi}

Bagong suyanto, 2005. Metode Penelitian social berbagai Alternatif Pendekatan. Jakarta : Prenada Media

Mathis. 2002. Manajemen Sumber Daya Manusia. Edisi pertama, Cetakan pertama. Yogjakarta : Salemba Empat

Nugroho Riant, 2004, Kebijakan public Formulasi, Implementasi dan Evaluasi. Gramedia Jakarta

Straus dan Corbin, 2003, Dasar - Dasar Penelitian Kualitatif, Yogyakarta: Pustaka Pelajar

Sugiono, 2009, Memahami Penelitian Kualitatif, Bandung : Alfabet

Solichin Abdul Wahab. 2010. Analisis kebijaksanaan Dari Formulasi ke Implementasi Kebijaksanaan Negara, Jakarta : PT Bumi Aksara

Subarsono, AG, 2010, Analisis Kebijakan Publik, Konsep, Teori dan Aplikasi, Yogyakarta, Pustaka Pelajar sudarsono, 2003, Beberapa Pendekatan Dalam penelitian Kualitatif, Yogyakarta : Gadjah Mada University Press.

Tjiptono, Fandy. 2000, Service Quality \& Satisfaction, Jakarta: Erlangga.

Thoha, 1998. Perspektif Perilaku Birokrasi, Jakarta: Rajawali Press

Zeithaml, Valerie A. and Mary Jo Bitner. 2006. Service Marketing Integrated, Cutomer focus

Zulian, Yamit. 2005, Manajemen Produksi dan Operasi Edisi Pertama, Penerbit Ekonisia Kampus Fakultas Ekonomi UII Yogyakarta. 